\title{
Molecular Phylogeny of the Genus Lathyrus (Fabaceae-Fabeae) Based on cpDNA matKSequence in Iran
}

\author{
Roghayeh Oskoueiyan ${ }^{1, ;} ;$ Shahrokh Kazempour Osaloo ${ }^{2}$; Atefeh Amirahmadi ${ }^{3}$ \\ ${ }^{1}$ Department of Biology, Ayatollah Amoli Branch, Islamic Azad University, Amol, I.R. IRAN \\ ${ }^{2}$ Department of Plant Biology, Faculty of Biological Sciences, Tarbiat Modares University, Tehran, I.R. IRAN \\ 3 Department of Biology, Damghan University, Damghan, I.R. IRAN \\ ${ }^{*}$ Corresponding author: Roghayeh Oskoueiyan, Department of Biology, Ayatollah Amoli Branch, Islamic Azad University, Amol, I.R. IRAN. Shahrokh Kazempour Osaloo, Department \\ of Plant Biology, Faculty of Biological Science, Tarbiat Modares University, Tehran, I.R. IRAN, Tel:+98-9125180684, Fax:+98-88249642, E-mail: ro.osko@gmail.comskosaloo@modares. \\ ac.ir
}

Received: January 16, 2013; Revised: June 8, 2013; Accepted: January 7, 2014

\begin{abstract}
Background: More than 60 species of the genus Lathyrus are distributed in Southwest Asia. It is the second largest genus of the tribe Fabeae, after Vicia, in the region (and in Iran with 23 species). In the regional Flora (Flora of Turkey, Flora Iranica and flora of Iran), the genus has been divided into 9-10 sections. Here we analyzed the phylogeny of Lathyrus and its relationship with Pisum based on plastid gene matK sequences.

Objectives: The present study utilized several approaches including maximum parsimony, Bayesian and maximum likelihood methods to evaluate the monophyly and relationship within the genus Lathyrus, both at the sectional level and species level, mainly based on the taxa growing in Iran.

Materials and Methods: A total of 52 accessions, representing 38 species of Lathyrus, three species of Pisum and four species of Vicia and Lens as out-groups, were analyzed for reconstructing the phylogenetic relationship using chloroplast gene matK sequences. Maximum parsimony, Bayesian and maximum likelihood methods were used to construct phylogenetic trees.

Results: The present study indicated that Pisum was nested among Lathyrus species. Two members of the Lathyrus section, Clymenum (Lathyrus ochrus and L. Clymenum) with Pisum, formed a weakly supported clade as sister to the larger polytomy comprising the remainder of the Lathyrus species. Several sections of Lathyrus including Lathyrostylis, Lathyrus and Clymenum were monophyletic. Lathyrus roseus (of the monotypic section Orobon) were nested among the members of section Lathyrus. The newly taxon described species L. alamutensis, endemic to Iran, were nested among other species of Lathyrostylis. Linearicarpus, Orobus and Pratensis were not monophyletic sections. Pratensis and the monotypic section Aphaca were the closest taxa. In our analysis, L. Pratensis formed a sister group relationship with the Aphaca clade, not its own section.

Conclusions: Shimodaira-Hasegawa (SH) test of the matK data set showed that all of the analyzed Lathyrus species formed their own clade and Pisum was sister to them. Furthermore, when we removed the two above-mentioned Lathyrus species, the analysis retrieved Pisum, as a well-supported clade being sister to the Lathyrus calde.
\end{abstract}

Keywords:Fabaceae; Lathyrus; Tribe Fabeae

\section{Background}

The tribe Fabeae (= Vicieae) contains four genera, of which Lathyrus L. and Vicia L. with ca 160 species are the largest $(1,2)$. Lens Mill. with 4-6 species and Pisum L. with 4 species (Vavilovia formosa (Stev.) Fed. of the monotypic genus Vavilovia Fed. was treated as a part of Pisum as P. formosum (Stev.) Alef. (3) are small genera. Vicia is paraphyletic and along with Lens, as a monophyletic taxon, formed a sister group relationship with a clade of Lathyrus and Pisum (2-5). Species of Lathrys are distributed throughout the Northern Hemisphere, tropical East Africa and temperate South America. Its main center of diversity is in the Mediterranean and Irano-Turanian regions, with smaller centers in North and South America (2, 6-8). Many species of Lathyrus are used extensively as cover crops, for fodder (L. cicera L., L. hirsutus L. and L. sativus L.), as ornamentals (L. odoratus L. [sweet pea], L. latifolius L. [everlasting pea] and L. sylvestris L.) and as human food (L. sativus [grass pea, Indian pea, chuckling vetch], L. ochrus (L.) DC. and L. montanus Bernh. (with edible root tubers) and also for erosion control, as green manure and for medicine; toxins are present in some species, causing Lathyrism (2).

More than 60 species of the genus have been distributed in the Southwest Asia (2). In the regional Flora including Flora of Turkey (9), Flora Iranica (10) and Flora of Iran (11), the genus was divided into 9-10 sections. Almost three decades ago, Kupicha (6) based on morphological 
characters, by assessing the older classifications of the genus, proposed her sectional system encompassing $13 \mathrm{sec}$ tions, of which three were newly established: Orobus (L.) Gordon, Lathyrostylis (Griseb). Bassler, Pratensis Bassler, Neurolobus Bassler, Orobon Tamamshjan, Orobastrum Boiss, Viciopsis Kupicha, Linearicarpus Kupicha, Lathyrus, Aphaca (Miller) Dumort. Nissolia (Miller) Dumort, Clymenum (Miller) DC. and NotoLathyrus Kupicha. She divided section Orobastrum into three monotypic sections Orobastrum, Linearicarpus and Viciopsis. She included section Cicercula (Medic.) Gren. and Godr. in section Lathyrus and added a new section of South American species, NothoLathyrus. We followed her system of classification in the present study.

Dogan et al. (12) conducted a numerical taxonomic study on 52 species of Turkish Lathyrus using 40 external vegetative and floral morphological characters. They divided the genus into nine sections, of which section Gorgonia Dogan was described as a new taxon. Leht (13) based on cladistic analysis of 210 morphological characters suggest that all species of section Pratensis Bassler should belong to section Aphaca. He placed the monotypic section Orobon (with species L. roseus Steven) within section Orobus (13). Hitherto, several works based on molecular data have been conducted on the phylogeny of Lathyrus. Asmussen and Liston (7) sampled 42 species of Lathyrus based on cpDNA restriction site characters and their study included representatives of all sections but Viciopsis. They generally agreed with the sectional classification of Kupicha (6), yet they suggested that Orobon and Orobastrum should be transferred to the section Lathyrus, and NothoLathyrus to Orobus. Croft et al. (14) used Random Amplified Polymorphic DNA (RAPD) analysis on eight accessions of L. sativus and some allies species. Badr et al. (15) utilized Amplified-Fragment Length Polymorphism
(AFLP) data to examine the systematic relationship in section Lathyrus. Ben Brahim et al. (16) studied isozyme variation and phylogenetic relationships between ten species of the genus. Kenicer et al. (8) studied 53 species of the genus based on nrDNA ITS, cpDNA trnL-F and trnS-G sequence data (except members of two Kupicha's sections, Orobon and Viciopsis). Their results generally supported the monophyly of sections Lathyrus and Lathyrostylis, but questioned monophyly of the larger section Orobus.

\section{Objectives}

In this study, we examined the phylogenetic relationships among 38 species of the genus Lathyrus based on chloroplast gene matK. All species of the genus growing in Iran and some species from Turkey were included. Unlike some previous studies $(7,8)$ the present study employed several approaches including maximum parsimony, Bayesian and maximum likelihood methods to evaluate the monophyly and relationship within Lathyrus, both at the sectional level and species level.

\section{Materials and Methods}

\subsection{Taxon Sampling}

Fifty-two accessions for matK were analyzed. A total of 38 species representing eleven sections of Lathyrus (6) and three species of Pisum (including Vavilovia formosa, see 3) were included in the phylogenetic analyses using each of the separate datasets as well as the combined dataset. The two species of Lens and Vicia were chosen as outgroups according to previous studies $(4,5,7,8)$. List of the analyzed species along with their voucher information and GenBank accession numbers are presented in (Table 1).

\begin{tabular}{|c|c|c|}
\hline Species & DNA Source (Location, Voucher) & GenBank Accession No \\
\hline Section Aphaca & - & - \\
\hline Lathyrusaphaca $\mathrm{L}^{\mathrm{b}}$ & Iran: B. Alizadeh 1005 (WARCNH) & AB935057 \\
\hline Lathyrusaphaca L. $^{\mathrm{a}}$ & USDA 2865272 & AF522084 \\
\hline Lathyrusaphaca L. $^{\mathrm{a}}$ & Portugal: Schaefer, H & HM851115 \\
\hline Section Clymenum & - & - \\
\hline LathyrusClymenum L. $^{\text {a }}$ & Portugal: Schaefer, $\mathrm{H}$ & HM851116 \\
\hline Lathyrusochrus (L.) DC. ${ }^{\text {b }}$ & Turkey: H. Sagban 3137 (GAZI) & AB935075 \\
\hline Lathyrusochrus (L.) DC. ${ }^{\text {a }}$ & Portugal: Schaefer, H & HM851120 \\
\hline SectionLathyrostylis & - & - \\
\hline Lathyrusalamutensis Mozaffarian et al. ${ }^{\text {b }}$ & $\begin{array}{l}\text { Iran: Mozaffarian, Ahvazi \& Charkhchian } 88388 \\
\text { (TARI) }\end{array}$ & AB935055 \\
\hline Lathyrusarmenus (Boiss. \& Huet) Celak. ${ }^{b}$ & Turkey: Aytaç 8317 (GAZI) & AB935058 \\
\hline Lathyrusboissieri Sirj. ${ }^{\text {b }}$ & Iran: Runemark \& Mozaffarian 29308 (TARI) & AB935060 \\
\hline Lathyrusbrachypterus Celak. ${ }^{b}$ & Turkey: Aytaç \& A. Duman 5441(GAZI) & AB935061 \\
\hline Lathyruscyaneus(Steven) K. Koch. ${ }^{\text {b }}$ & Iran, Azerbayjan: Mozaffarian 70010 (TARI) & AB935065 \\
\hline Lathyrusdigitatus (M. Bieb) Fiori ${ }^{\mathrm{b}}$ & Turkey: M. Vural 4033 (GAZI) & AB935067 \\
\hline
\end{tabular}


Oskoueiyan R et al.

\begin{tabular}{|c|c|c|}
\hline Lathyruselongatus(Bornm.) Širj. ${ }^{\text {b }}$ & Turkey: F. Tezcan (GAZI) & AB935068 \\
\hline Lathyruskarsianus Davis ${ }^{\mathrm{b}}$ & Turkey: G. Akgül 1700 (GAZI) & AB935073 \\
\hline Lathyrustukhtensis Czecz. ${ }^{\mathrm{b}}$ & Turkey: A. Güner 5798 (GAZI) & AB935084 \\
\hline Lathyrusvariabilis (Boiss. \& Kotschy) Celak. b & Turkey: Z. Aytaç \& H. Duman 4599 (GAZI) & AB935085 \\
\hline Section Lathyrus & - & - \\
\hline Lathyrusannuus $\mathrm{L} .{ }^{\mathrm{b}}$ & Iran: Hewer 3676 (TARI) & AB935056 \\
\hline Lathyruscassius Boiss. ${ }^{\text {b }}$ & Iran: Neamati \& Ghaderi 4581(TARI) & AB935062 \\
\hline Lathyruschloranthus Boiss. ${ }^{\text {b }}$ & Iran: Kazempour 2008-5 (TMUH) & AB935063 \\
\hline LathyrusciceraL. ${ }^{\mathrm{b}}$ & Iran: Joharchi \& Zangooei 23122 (FUMH) & AB935064 \\
\hline Lathyrushirsutus $\mathrm{L}^{\mathrm{b}}$ & Iran: Naqinezhad 27738 (TUH) & AB935069 \\
\hline 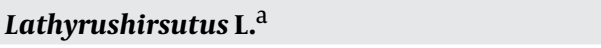 & Portugal: Schaefer, $\mathrm{H}$ & HM851117 \\
\hline LathyruslatifoliusL. $^{a}$ & Portugal: Schaefer, $\mathrm{H}$ & HM851118 \\
\hline Lathyrus pseudo-cicera Pamp. ${ }^{\text {b }}$ & Turkey: N. Adiguzell 2238 (GAZI) & AB935077 \\
\hline Lathyrusrotundifolius Willd. ${ }^{\text {b }}$ & Iran: Sonboli 496 (TMUH) & AB935080 \\
\hline Lathyrussativus L. ${ }^{\text {b }}$ & Iran: Alizadeh \& Zangooei 15589 (FUMH) & AB935081 \\
\hline 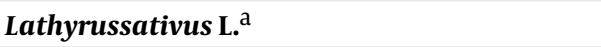 & USDA 283562 & AF522086 \\
\hline Lathyrustingitanus $\mathrm{L}^{\mathrm{a}}$ & USDA 451858 & AF522087 \\
\hline Lathyrustuberosus $\mathrm{L}^{\mathrm{b}}{ }^{\mathrm{b}}$ & Iran: Alizadeh et al., 5118 (WARCNH) & AB935083 \\
\hline Section Linearicarpus & - & - \\
\hline Lathyrusinconspicuus $\mathrm{L}^{\mathrm{b}}$ & Iran: Faghihnia \& Zangooei 34027 (FUMH) & AB935071 \\
\hline Lathyrussphaericus Retz. ${ }^{\mathrm{b}}$ & Iran: Joharchi \& Zangooei 33235 (FUMH) & AB935082 \\
\hline Lathyrusvinealis Boiss. \& Noe. ${ }^{\text {b }}$ & Iran: Wendelbo \& Assadi 16788 (TARI) & AB935087 \\
\hline Lathyrusworonowii Bornn. ${ }^{\text {b }}$ & Turkey: Z. Aytaç 8693 (GAZI) & AB935088 \\
\hline Section Orobon & - & - \\
\hline Lathyrusroseus Stev. ${ }^{\text {b }}$ & Turkey: Aytaç 8157 (GAZI) & AB935079 \\
\hline Section Orobus & - & - \\
\hline Lathyrus aureus (Steven) Brandza ${ }^{\text {b }}$ & Turkey: O. Eyüboÿlu 1661(GAZI) & AB935059 \\
\hline Lathyrus humilis (Ser.) Sprengel $^{\text {b }}$ & USSR: Ivanovsky 2894b (TARI) & AB935070 \\
\hline Lathyrusincurvus(Roth) Willd. b & Iran: Kazempour 2008-4 (TMUH) & AB935072 \\
\hline Lathyrusjaponicus Willd ${ }^{\mathrm{a}}$ & Portugal: Schaefer, $\mathrm{H}$ & HM851119 \\
\hline quinquenervis (Miq) Litv ${ }^{\mathrm{b}}$ & USSR: Sukatschew \& Poplawska 2898 (TARI) & AB935078 \\
\hline Lathyrusvernus(L.) Bernh. ${ }^{b}$ & Iran: Runemark \& Mozaffarian 28061 (TARI) & AB935086 \\
\hline Section Ratensis & - & - \\
\hline Lathyrusczeczottianus Bassler ${ }^{\text {b }}$ & Turkey: O. Eyüboÿlu 1308 (GAZI) & AB935066 \\
\hline Lathyruslaxiflorus(Desf.) Kuntze ${ }^{\mathrm{b}}$ & Faghihnia, Rafeiee \& Zangooei 25516(FUMH) & AB935074 \\
\hline LathyrusPratensis L. ${ }^{\text {b }}$ & Iran: Heidari et al. 1803 (WARCNH) & AB935076 \\
\hline Pisum formosum (Stev.) Alef. ${ }^{\text {b }}$ & Iran: Mozaffarian 88389 (TARI) & AB935089 \\
\hline Pisumformosum (Stev.) Alef. ${ }^{\text {b }}$ & Turkey: M. Vural \& N. Adigüzel s.n. (GAZI) & AB935090 \\
\hline Pisumfulvum Sibth \& Sm. b & Turkey: Adiguzel \& Aytaç 1896 (GAZI) & AB935091 \\
\hline Pisumsativum ${ }^{\mathrm{b}}$ & Iran: Alizadeh et al. 1225 (WARCNH) & AB935092 \\
\hline Lens cyanea(Boiss \& Hohen.) Alef. b & Iran: Joharchi 34755-a (FUMH) & AB935093 \\
\hline Lens ervoides (Brign.) Grande ${ }^{b}$ & Turkey : R. M. Nesbitt \& D. Samuel 2297 (GAZI) & AB935094 \\
\hline Lens ervoides (Brign.) Grande ${ }^{a}$ & USDA 572330 & AF522090 \\
\hline Vicia ervilia (L.) Willd. ${ }^{\text {b }}$ & $\begin{array}{l}\text { Iran: Emadzadeh, Memariani \& Zangooei } 36169 \\
\text { (FUMH) }\end{array}$ & AB935095 \\
\hline Vicia hyrcanica Fisch. \&. Mey. ${ }^{\text {b }}$ & Iran: Memariani \& Zangooei 38986 (FUMH) & AB935096 \\
\hline \multicolumn{3}{|c|}{$\begin{array}{l}{ }^{\circ} \text { Abbreviations: WARCNH, West Azerbaijan Research Center of Natural Resources and Agriculture Herbarium; FUMH, Ferdowsi University of Mashhad } \\
\text { Herbarium, Mashhad, Iran; GAZI, Gazi University Herbarium, Ankara, Turkey; TMUH, Tarbiat Modares University Herbarium, Tehran, Iran; TUH, Tehran } \\
\text { University Herbarium, Tehran, Iran;TARI, Herbarium of the Research Institute of Forests and Rangelands, Tehran, Iran; USDA, seeds accessions obtained } \\
\text { from US Department of Agriculture Plant Introduction program. With the exception of TMUH and WARCNH, herbarium acronyms are according to } \\
\text { Holmgren and Holmgren (17). } \\
\text { a Sequences of matK region for those taxa were retrieved from GenBank } \\
\text { b Sequences of matK region for those taxa were determined in this study }\end{array}$} \\
\hline
\end{tabular}




\subsection{DNA Isolation, PCR and Sequencing}

Total genomic DNA was isolated from leaf material (stipules of Lathyrus aphaca L.) using the modified Cetyltrimethyl Ammonium Bromide (CTAB) method of Doyle and Doyle (18). The chloroplast gene matK was used. The partial matK gene was amplified using primers matK384F (designed in this study) and trnK2R (5). Total volume of amplification reactions was $20 \mu \mathrm{L}$, which contained 8.2 $\mu \mathrm{L}$ deionized water, $10 \mu \mathrm{L}$ of the $2 \times$ Taq DNA polymerase master mix Red (Amplicon, Cat. No. 180301, 150 mM TrisHCL pH 8.5, $40 \mathrm{mM}\left(\mathrm{NH}_{4}\right) 2 \mathrm{SO}_{4}, 3.0 \mathrm{mM} \mathrm{MgCl} 2,0.4 \mathrm{mM}$ dNTPs, 0.05 units. $\mu \mathrm{L}^{-1}$ Amplicon Taq DNA polymerase, inert red dye and a stabilizer) $0.5 \mu \mathrm{L}$ of each primer ( 5 pmol. $\left.\mu \mathrm{L}^{-1}\right)$ and $1 \mu \mathrm{L}$ of template DNA $\left(20 \mathrm{ng} . \mu \mathrm{L}^{-1}\right)$. The PCR cycles consisted of predenaturation at $95^{\circ} \mathrm{C}$ for $2.30 \mathrm{~min}$ utes followed by 35 cycles: denaturation at $94^{\circ} \mathrm{C}$ for 45 seconds, annealing at a temperature depending on the region, at $51^{\circ} \mathrm{C}$ for matK and elongation at $72^{\circ} \mathrm{C}$ for 1.20 minutes. A final elongation step of seven minutes at $72^{\circ} \mathrm{C}$ was performed. Each region was sequenced using the 'Big dye terminator cycle sequencing ready reaction kit' with appropriate primers in an ABI Prism 3730XL DNA analyzer.

\subsection{Sequence Alignment}

The dataset was aligned using CLUSTAL (19) and adjusted manually. Positions of insertions and deletions were treated as missing data.

\subsection{Phylogenetic Analyses}

\subsubsection{The Maximum Parsimony Method}

Maximum Parsimony (MP) analyses were conducted using the PAUP* version 4.0b10 (20) for phylogenetic analysis. The heuristic search option was employed for the dataset, using tree bisection-reconnection (TBR) branch swapping, with 1000 replications of random addition sequence and an automatic increase in the maximum number of trees. Uninformative characters were excluded from the analysis. Branch support values were calculated using a full heuristic search with 1000 bootstrap (BS) replicates (21) each with simple addition sequence.

\subsubsection{Bayesian Method}

Model of sequence evolution for the dataset was selected using the program MrModeltest version 2.3 (22) as implemented in MrMTgui (23) based on the Akaike information criterion (AIC) (24). The matK dataset was analyzed using the GTR + I + G model. The program MrBayes (25) was used for the Bayesian phylogenetic analysis. Posteriors on the model parameters were estimated from the data, using the default priors. The analysis was done with four million generations, using Markov chain Monte Carlo search. MrBayes performed two simultaneous analyses starting from different random trees (Nruns $=2$ ) each with four Markov chains and trees sampled at every 100 generations. The first $25 \%$ of trees were discarded as the burn-in. The remaining trees were then used to build a $50 \%$ majority rule consensus tree accompanied with posterior probability (PP) values. Tree visualization was carried out using Tree View version 1.6.6.

\subsubsection{Maximum Likelihood}

Maximum likelihood (ML) analyses were performed for the datasets in the program Genetic Algorithm for Rapid Likelihood Inference (GARLI) (26). The model of evolution employed for each data set was the same as that of Bayesian analyses.

Parametric bootstrap values for ML were calculated in GARLI, based on 100 replicates with one search replicate per bootstrap replicate.

\subsubsection{Shimodaira-Hasegawa Test}

Shimodaira-Hasegawa (SH) test (27) in PAUP*, based on maximum likelihood analyses was used to test the hypothesis that Lathyrus is monophyletic and Pisum is the sister group for Lathyrus. To accept that the hypothesis probability value (P-value) should be more than 0.05 .

\section{Results}

\subsection{Sequence Dataset}

The aligned matK dataset was 1077 nucleotide sites long, of which 186 sites were potentially parsimony informative. The length of matK varies from 623 BP in Lathyrus aphaca, L. ochrus, L. Clymenum L., L. tingitanus L. and L. latifolius (the smaller length of matK gene for these species is due to incomplete sequencing, which was retrieved from GenBank) to 1065 in L. alamutensis Mozaffarian, Ahvazi \& Charkhchian. Parsimony analysis of the dataset resulted in 10000 trees of length $(\mathrm{L})=468$ steps, Consistency In$\operatorname{dex}(\mathrm{CI})=0.519$ and Retention Index $(\mathrm{RI})=0.798$. The $50 \%$ majority rule consensus tree resulting from the Bayesian analysis of the matK dataset with posterior probabilities and bootstrap values is shown in Figure 1.

In the present study, for all trees derived from MP, Bayesian and ML methods, Pisum was nested among Lathyrus species. Two members of the section Clymenum (Lathyrus ochrus and L. Clymenum) with Pisum subclade formed a weakly supported clade as sister to larger polytomy comprising the remainder Lathyrus species.

Here, we described the relationship between the taxa based upon the tree from Bayesian analysis (Figure 1). All multi-specific sections of Lathyrus (Lathyrostylis, Lathyrus and Clymenum), with the exception of Linearicarpus, Orobus and Pratensis were well-supported monophyletic groups. Pratensis and the monotypic section Aphaca were the closest taxa. Results of the SH test based upon the dataset showed that Lathyrus is a monophyletic taxon and Pisum is sister to this taxon $(\mathrm{P}>0.05)$. 


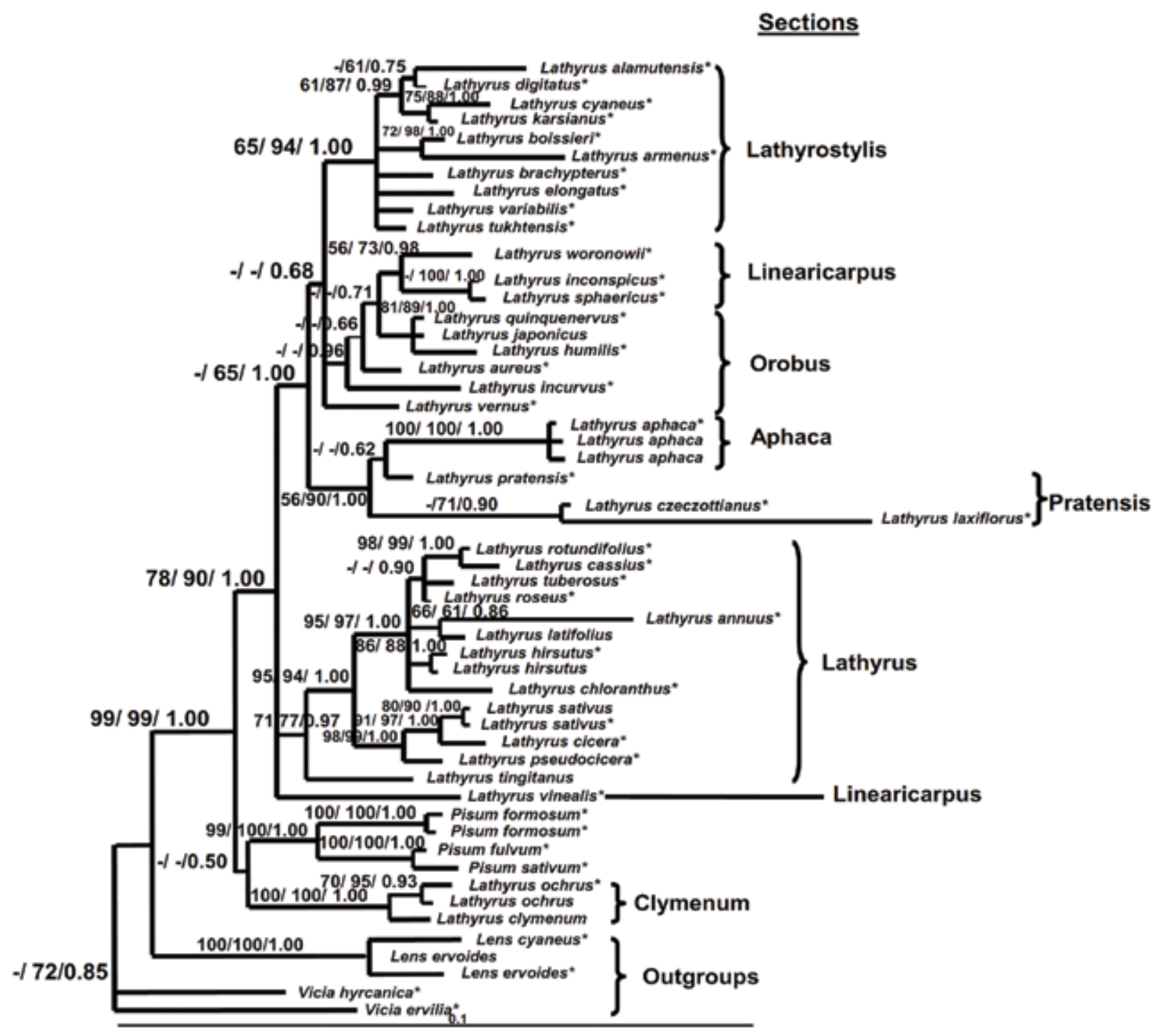

Figure 1. 50\% Majority Rule Consensus Tree Resulting from Bayesian Analyses of the matK Data Set. Numbers above branches are maximum parsimony (MP) bootstrap/maximum likelihood (ML) bootstrap/posterior probabilities (pp), values $<50 \%$ are not shown. "matKgenes was newly sequenced for these taxa

\section{Discussion}

\subsection{Phylogenetic Status of the Genus Lathyrus}

Kupicha (6) and Lock \& Maxted (2) stated that Lathyrus is a monophyletic genus. In studies of Steele et al. (4) and Kenicer et al. (8), Pisum sativum L. along with species of Lathyrus formed a clade with bootstrap value of $100 \%$. In the latter work, Lathyrus species, with the inclusion of sections Nissolia, Clymenum and Neurolobus, formed a weakly supported clade (bootstrap value of $<50 \%$ ). In the present study, at the base of the tree, the Pisum clade was weakly allied with L. ochrus and L. clymenum (sect. Clymenum) and thus, Lathyrus was not monophyletic (Figure 1). SH test (p $>0.05$ ) of the dataset showed that all analyzed Lathyrus species formed their own clade and Pisum was sister to them. Furthermore, when we removed these two Lathyrus species, the analysis retrieved Pisum as a well-supported clade being sister to Lathyrus calde (tree not shown). Lathyrus and Pisum are similar in some morphological characters, including presence of pollen brush on the adaxial side of the style; non-brochiododromous leaflet venation (i.e. veins reaching the margins) and accumulate pisatin, a phytoalexin that is not found in other members of Fabeae. In addition, both genera lack canavanine (4, 8, 28-31). The two genera, however, differ in some diagnostic char- 
acters as conduplicate or folded leaflet ptyxis and folded longitudinal style in Pisum (except P. formosum for the former character), but super volute or rolled ptyxis and non-folded longitudinal style in Lathyrus $(1,4)$. Moreover, the wider hybridization experiments between Lathyrus and Pisum species have shown cross-incompatibility (32).

\subsection{Relationships within Lathyrus}

The tree resulting from the dataset composed of several clades. Some of the clades had also appeared in previous molecular studies $(7,8)$; albeit the relationships were well resolved and supported in our tree. Below we examine some of these lineages.

\subsection{Section Orobus}

Kupicha (6) accepted the heterogeneous section Orobus with 54 species having a perennial habit, multijugate leaves with or without tendrils. As she noted, "the section contains a diversity of vegetative and floral forms and many of its members appear to be rather distantly related".

Our matK analysis did not retrieve section Orobus as a monophyletic group. This is in agreement with the conclusion made by Kenicer et al. (8). Lathyrus vernus (L.) Bernh, L. incurvus (Roth) Willd and L. aureus (Steven) Bran$\mathrm{dza}$, are successive sisters to a subclade of three species $L$. quinquenervus (Miq.) Litv. L. japonicus Willd. and L. humilis (Ser.) Sprengel (all of sect. Orobus) $(\mathrm{BS}=81 \%, 89 \%$ and $\mathrm{pp}=$ 1.00 ) and sect. Linearicarpus (L. woronowii Bornm, L. inconspicuus L. and L. sphaericus Retz.). Kupicha (6) claimed that a few species of section Orobus (e.g. L. quinquenervus, $L$. alpestris (Waldst. \& Kit.)) are closely related to members of section Lathyrostylis, whereas our analysis did not show a direct relationship between these two sections.

\subsection{Sections Aphaca and Pratensis}

The present study is concordant with previous reports (6-8) regarding the close relationship of sections Apha$\mathrm{ca}$ and Pratensis. They do share large hastate stipules, a unique pattern of nodal anatomy and distinctive wing petal architecture. Aphaca is a ditypic section and Pratensis is a small section comprising six species (6). The former section is represented by a single species (L. apha$\mathrm{ca}$ ) with three accessions, and the second one by three species with three accessions (L. Pratensis L., L. laxiflorus (Desf.) Kuntze and L. czeczottianus Bassler). In our analysis, L. Pratensis formed a sister group relationship with the Aphaca clade not its own section.

\subsection{Section Lathyrus}

In our results, all members of the section Lathyrus with inclusion of $L$. roseus Steven (of the monotypic section Orobon) formed a well-supported clade (BS $=71 \%, 77 \%$ and $\mathrm{pp}=0.97$ ). Within this calde, L. tingitanus is well allied with the remainder species. The remainder species made up two subclades. One subclade included only annual species, L. cicera, L. pseudocicera Pampan. and L. sativus ( $\mathrm{BS}=99 \%, 98 \%$ and $\mathrm{pp}=1.00$ ), which were previously classified under either section Cicercula (Medic.) Godr. $(9,10,33)$ or section Clymenum (11). These species are characterized by a canaliculate style. The second subclade comprised of both annual and perennial species (BS $=97 \%, 95 \%$ and pp $=1.00$ ). Members of this subclade were already placed in sections Cicercula (annuals), Lathyrus (perennials) and the monotypic Orobon (L. roseus) $(9,10,33)$. Kupicha (6) questioned the monophyly of section Cicercula and synonymized it with sect Lathyrus. This treatment was confirmed and followed by Kenicer et al. (8) and the present study. However, Kupicha maintained section Orobon (L. roseus) by suggesting that a bushy habit and isodiametric and strongly wavy-walled epidermal cells distinguishes this group from the species of section Lathyrus. Yet, the flower and fruit characteristics agree entirely with those of section Lathyrus (6). She claimed that this species is related to the delicate perennials (e.g. L. tuberosus L.) of the section Lathyrus. Indeed, in the present study and Asmussen and Liston's (7) analyses, this species was allied with L. tuberosus. Hence, we are in agreement with Asmussen and Liston (7) in that the section Orobon should be combined with section Lathyrus.

\subsection{Section Lathyrostylis}

Lathyrostylis (= Platystylis) is a relatively uniform section comprising 21 species $(6,12)$, of which 10 species were included. Our matK as well as the combined (nrDNA ITS, trnL-F and trnS-G) sequence data of Kenicer et al. (8) indicated that this section formed a well-supported clade ( $\mathrm{BS}=94 \%, 65 \%, \mathrm{PP}=1.00$ ). Czefranova (33) placed species of this section within section Orobus. However, Bassler (34) and later Kupicha (6) suggested that the two sections are distinct. The current study and previous molecular studies clearly showed that members of section Lathyrostylis are not related to section Orobus, supporting the recent morphology-based treatments $(6,34)$. It is important to note that the section is represented by three species L. cyaneus (Stev.) C. Koch, L. boissieri Sirj. and L. alamutensis in Iran only, of which, the latter was recently established as a new species from western Alborz mountain ranges. This new species has very specific characteristics with two flap-like appendages above the claw of standard (35).

Linearicarpus is a small section with seven annual species of which four were analyzed here (6). Analysis of matK sequence data revealed that the section at the current status is not monophyletic. Its three species $L$. inconspicuus, L. sphaericus and L.woronowii are closely related taxa and allied with some members of section Orobus. Yet, L. vinealis Boiss. \& Noe (fourth species), falls distantly from them in a trichotomy. Previous morphology (12) and molecular-based $(7,8,15)$ analyses questioned 
the monophyly of this section. It should be mentioned that in Flora of Turkey (9) and Flora Iranica (10), L. inconspicuus, $L$. sphaericus, $L$. vinealis and $L$. woronowii plus some others were placed in section Orobastrum, whereas in Flora of Iran (11), they along with L. nissolia were classified under sect. Nissolia. Kupicha (6) combined section. Orobastrum with sect. Linearicarpus and recognized Nissolia as a monotypic section.

\subsection{Section Clymenum}

The section Clymenum is composed of only three annual species, L. gloeospermus Warb. \& Eig., L. Clymenum and $L$. ochrus. Previous researchers $(7,8)$ by analyzing all these three species questioned the monophyly of this section. They all reached the same conclusion as ours, claiming that $L$. Clymenum and $L$. ochrus are closely related taxa. Although, L. gloeospermus was well separated from the remainder of the section. In contrast to the latter species, L. Clymenum and L. ochrus do share several floral features including hollow, finger-like pouches on the standard, an unusual type of style (spathulate with apex ended to sterile fleshy mucro or arista which divides the stigma into two halves) and pods with winged sutures (6).

\section{Acknowledgements}

The authors thank the staff of the herbaria of West Azerbaijan Research Center of Natural Resources and Agriculture Herbarium, Ferdowsi University of Mashhad Herbarium, Gazi University Herbarium, Tehran University Herbarium, Herbarium of the Research Institute of Forests and Rangelands, for providing leaf materials.

\section{Authors' Contribution}

All authors participated equally in the study

\section{Financial Disclosure}

There was no conflict of interest.

\section{Funding/Support}

Funding was provided by the Islamic Azad University, Ayatollah Amoli Branch.

\section{References}

1. Kupicha F. K. V. . Advances in Legume Systematics. polhill RRP editor. london: Royal Bot. Gard., Kew.; 1981.

2. Maxted N. F. , Lock.. Legumes of the world. Lewis G, Schrire B, Mackinder B, Lock M editors. London: Royal Botanic Gardens, Kew; 2005.

3. Oskoueiyan R, Kazempour OS, Maassoumi AA, Nejadsattari T, Mozaffarian V. Phylogenetic status of Vavilovia formosa (FabaceaeFabeae) based on nrDNA ITS and cpDNA sequences. Biochemical Systematics and Ecology. 2010;38(3):313-9.

4. Steele KP, Wojciechowski MF. Phylogenetic analyses of tribes Trifolieae and Vicieae, based on sequences of the plastid gene matK (Papilionoideae: Leguminosae). Advances in legume systematics, part. 2003;10:355-70.

5. Wojciechowski MF, Lavin M, Sanderson MJ. A phylogeny of le- gumes (Leguminosae) based on analysis of the plastid matK gene resolves many well-supported subclades within the family. Am J Bot. 2004;91(11):1846-62.

6. Kupicha FK. infrageneric structure of Lathyrus. Notes-Royal Botanic Garden Edinburgh. 1983;41:209-44.

7. Asmussen CB, Liston A. Chloroplast DNA Characters, Phylogeny, and Classification of Lathyrus (Fabaceae).Am J Bot.1998;85(3):387.

8. Kenicer GJ, Kajita T, Pennington RT, Murata J. Systematics and biogeography of Lathyrus (Leguminosae) based on internal transcribed spacer and cpDNA sequence data. Am J Bot. 2005;92(7):1199-209.

9. Davis PH, Cullen J, Coode JE. Flora of Turkey and the East Aegean Islands.Edinburgh: University Press; 1988.

10. Rechinger KH. Lathyrus . In: Rechinger KH editor. Flora Iranica: Graz; 1979. pp. 61-82.

11. Neamati M. Vicieae-Lathyrus. In: Assadi MMAKMMV editor. Flora of Iran.. Tehran: Research Institute of Forests and Rangelands; 2000. pp. 110-48.

12. Dogan M, Kence A, Tigin C. Numerical taxonomic study on Turkish Lathyrus (Leguminoseae). Edinburgh Journal of Botany. 2010;49(3):333.

13. Leht M. phylogeny of Old World Lathyrus L. (Fabaceae) based on morphological data. J Bot Taxon Geobot. 2009;120:59-74.

14. Croft AM, Pang ECK, Taylor PWJ. Molecular analysis of Lathyrus sativus L. (grasspea) and related Lathyrus species. Euphytica. 1999;107(3):167-76.

15. Badr A, Shazly H, Rabey H, Watson LE. Systematic relationships inLathyrussect.Lathyrus(Fabaceae) based on amplified fragment length polymorphism (AFLP) data. Can J Bot. 2002;80(9):962-9.

16. Ben Brahim N, Salhi A, Chtourou N, Combes D, Marrakchi M. Isozymic polymorphism and phylogeny of 10 Lathyrus species. GENET RESOUR CROP EV. 2002;49(4):429-38.

17. Holmgren PK, Holmgren NH. A Global Directory of Public Herbaria and Associated Staff. 1998. Available from: http://sweetgum.nybg. org/ih.

18. Doyle JJ. A rapid DNA isolation procedure for small quantities of fresh leaf tissue. Phytochem. Bull.1987;19:11-5.

19. Larkin MA, Blackshields G, Brown NP, Chenna R, McGettigan PA, McWilliam H, et al. Clustal W and Clustal X version 2.0. Bioinformatics. 2007;23(21):2947-8.

20. Howard TJ, Swofford JB, Wagner DL, Sherman S, Lehman GA. Quality of life after bilateral thoracoscopic splanchnicectomy: longterm evaluation in patients with chronic pancreatitis. J Gastrointest Surg. 2002;6(6):845-52.

21. Felsenstein J. Confidence Limits on Phylogenies: An Approach Using the Bootstrap. Evolution. 1985;39(4):783.

22. Nylander JAA. MrModeltest v2. Program distributed by the author. Evolutionary Biology Centre, Uppsala University. 2004;2.

23. Nuin P. MrMTgui 1.0 (version 1.6). Program distributed by the author. 2005.

24. Posada D, Buckley TR. Model selection and model averaging in phylogenetics: advantages of akaike information criterion and bayesian approaches over likelihood ratio tests. Syst Biol. 2004;53(5):793-808.

25. Ronquist F, Huelsenbeck JP. MrBayes 3: Bayesian phylogenetic inference under mixed models. Bioinformatics. 2003;19(12):1572-4.

26. Gutell RR, Jansen RK. . Genetic algorithm approaches for the phylogenetic analysis of large biological sequence datasets under the maximum likelihood criterion.. USA: University of Texas,Austin; 2006.

27. Shimodaira H, Hasegawa M. Multiple Comparisons of Log-Likelihoods with Applications to Phylogenetic Inference. Molecular Biology and Evolution. 1999;16(8):1114-6.

28. KUPICHA FK. Observations on the vascular anatomy of the tribe Vicieae (Leguminosae). Botanical Journal of the Linnean Society. 1975;70(3):231-42.

29. Gunn CR, Kluve J. Androecium and Pistil Characters for Tribe Vicieae (Fabaceae). Taxon. 1976;25(5/6):563.

30. Ingham JL. Phytoalexin induction and its chemosystematic significance in the genus Trigonella. Biochemical Systematics and Ecology. 1981;9(4):275-81.

31. Wingrove F, Porter P, Bisby G, May C. Perceptions on occupational satisfaction among Iowa dentists. Iowa Dent J.1994;80(3):23-4. 


\section{Oskoueiyan R et al.}

32. Ochatt SJ, Benabdelmouna A, Marget P, Aubert G, Moussy F, Pontécaille $\mathrm{C}$, et al. Overcoming hybridization barriers between pea and some of its wild relatives. Euphytica. 2004;137(3):353-9.

33. Czefranova Z. Conspectus systematic generis Lathyrus L. Nov. Syst. Pl. Vasc. 1971;;8:191-201.
34. Bässler M. Revision von Lathyrus L. sect. Lathyrostylis (Griseb.) Bässler (Fabaceae). Feddes Repertorium. 2008;92(3):179-254.

35. Mozaffarian V, Ahavazi M. Charkhchian M. M. A new species of the genus Lathyrus (Papilionaceae) from Iran. Iran. J. Bot. 2008;14(1):7-9. 